\title{
Analysis of the problem on preparing future primary school teachers for the organization of pupils' labor training
}

\section{Análise do problema de preparar futuros professores da escola primária para a organização do treinamento para o trabalho dos alunos}

\section{Análisis del problema de la preparación de los futuros profesores de primaria para la organización de la formación laboral de los alumnos}

\author{
Iryna Oleksandrivna Palshkova ${ }^{(D)}$, Viktoriia Anatoliivna Balakirieva ${ }^{1}$ (D), \\ Marianna Volodymyrivna Skoromna ${ }^{1}$ (D), Yuliia Anatoliivna Shpaliarenko ${ }^{1}$
}

${ }^{1}$ South Ukrainian National Pedagogical University named after K.D. Ushynsky, Odessa, Ukraine.

\section{Corresponding author:}

Viktoriia Anatoliivna Balakirieva

Email: viktoriia.balakirieva@bk.ru

How to cite: Palshkova, I. O., Balakirieva, V. A., Skoromna, M. V., \& Shpaliarenko, Y. A. (2021). Analysis of the problem on preparing future primary school teachers for the organization of pupils' labor training. Revista Tempos e Espaços em Educação, 14(33), e16091. http://dx.doi.org/10.20952/revtee.v14i33.16091

\begin{abstract}
Analysis of the problem on preparing future primary school teachers for the organization of pupils' labor training. The preparation of future primary school teachers for organizing labor training of young learners in the educational process of high school has been analyzed in the article. The essence and structure of the "readiness of future teachers to organize labor training of young learners" phenomenon have been revealed. The preparation of future primary school teachers for the organization of labor training of young learners in the educational process of high school has been monitored. The problems of young learners' labor training have been discussed, and the forms and methods for preparing future primary school teachers for the organization of labor training have been developed. Preparation as a general concept is interpreted as an organized, purposeful long-term educational process in different types of educational institutions whose ultimate aim is to achieve the readiness to carry out professional pedagogical activities in a particular specialty. Readiness of future primary school teachers to organize labor training is interpreted as a result of preparing students during their studies at a higher pedagogical institution, as the state of the future teacher who has mastered the system of knowledge on productive, project technologies. The formation of future primary school teachers' readiness is not a spontaneous or involuntary process. This is a systematic and purposeful activity.
\end{abstract}

Keywords: Preparation. Readiness for The Organization of Labor Training. Young Learner. Future Primary School Teacher. Labor Training. 


\section{RESUMO}

Análise da problemática da preparação dos futuros professores do ensino básico para a organização da formação profissional dos alunos. No artigo é analisada a preparação dos futuros professores do ensino fundamental para a organização da formação profissional de jovens no processo educacional do ensino médio. Foi revelada a essência e a estrutura do fenômeno da "prontidão dos futuros professores para organizar a formação profissional de jovens aprendizes". Acompanhou-se a preparação dos futuros professores do ensino fundamental para a organização da formação profissional de jovens no processo educacional do ensino médio. Os problemas da formação para o trabalho dos jovens alunos foram discutidos e as formas e métodos para preparar os futuros professores do ensino primário para a organização da formação para o trabalho foram desenvolvidos. A preparação como um conceito geral é interpretada como um processo educacional de longo prazo organizado e proposital em diferentes tipos de instituições de ensino, cujo objetivo final é alcançar a prontidão para realizar atividades pedagógicas profissionais em uma especialidade específica. A prontidão dos futuros professores do ensino fundamental para organizar a formação profissional é interpretada como resultado da preparação dos alunos durante seus estudos em uma instituição pedagógica superior, como o estado do futuro professor que domina o sistema de conhecimento em tecnologias de projeto produtivas. A formação da prontidão dos futuros professores do ensino fundamental não é um processo espontâneo ou involuntário. Esta é uma atividade sistemática e proposital.

Palavras-chave: Preparação. Preparação para o treinamento da Organização do Trabalho. Jovem aprendiz. Futuro Professor da Escola Primária. Treinamento de mão de obra.

\section{RESUMEN}

Análisis del problema de la preparación de los futuros profesores de primaria para la organización de la formación laboral de los alumnos. En el artículo se analiza la preparación de los futuros profesores de primaria para la organización de la formación laboral de los jóvenes en el proceso educativo de secundaria. Se ha revelado la esencia y la estructura del fenómeno de la "disposición de los futuros profesores para organizar la formación laboral de los jóvenes estudiantes". Se ha monitoreado la preparación de los futuros maestros de primaria para la organización de la formación laboral de los jóvenes estudiantes en el proceso educativo de la escuela secundaria. Se han discutido los problemas de la formación laboral de los jóvenes y se han desarrollado las formas y métodos para preparar a los futuros maestros de escuela primaria para la organización de la formación laboral. La preparación como concepto general se interpreta como un proceso educativo organizado, intencionado a largo plazo en diferentes tipos de instituciones educativas cuyo fin último es lograr la disposición para realizar actividades pedagógicas profesionales en una especialidad determinada. La disposición de los futuros docentes de primaria para organizar la formación laboral se interpreta como resultado de la preparación de los estudiantes durante sus estudios en una institución pedagógica superior, como el estado del futuro docente que ha dominado el sistema de conocimientos sobre tecnologías productivas de proyectos. La formación de la preparación de los futuros maestros de escuela primaria no es un proceso espontáneo o involuntario. Esta es una actividad sistemática y con un propósito.

Palabras clave: Preparación. Preparación para la organización de la formación laboral. Joven aprendiz. Futura Maestra de Educación Primaria. Capacitación laboral.

\section{INTRODUCTION}

In modern conditions, it is important to fully take into account new requirements for preparing teachers, including professionals of the new generation who have competitive qualification and should not only be good at typical pedagogical situations, but should also organize young learners' educational activities based on purposeful and methodologically reasonable use of 
concepts of the learner-centered and competence-based education. Such changes are an important means of innovative renewal of the national system of pedagogical education because they direct future primary school teachers to the vocational activities in the new conditions of school development. Current trends in the development of the national education system require theoretical substantiation and practical updating of the content and methods of professional preparation of teachers who work with children. When obtaining education in pedagogical higher educational institutions, a future primary school teacher must carefully prepare for young learners' labor training by mastering efficient approaches, technologies, and guidelines. Thus, the relevance of studying the organization of young learners' labor training in primary school and the lack of pedagogical studies that would carry out the scientific and theoretical analysis and summarize the experience of labor training in accordance with modern social transformations and economic development, as well as the need to overcome a number of contradictions between understanding the role of labor training in the formation of young learners' personality and the lack of provisions on the integral readiness for primary school teachers' vocational activity; opportunities of the educational process in primary school and the lack of developed methods of forming young learners' productive labor activity; the need in professional preparation of future primary school teachers for the productive and labor activity and the lack of proper methodological support for such preparation enable the authors to conclude that nowadays the pedagogical science does not fully reveal the historical and pedagogical aspect of the problem on teaching young learners, does not generalize the leading ideas of national and foreign teachers on this issue, does not reveal the content of primary education, as well as the practical experience of teaching children in primary schools.

The hypothesis of the study is that the dominant motives of young learners determine a responsible attitude to learning and largely depend on the motives guiding a learner during labor training. The need in preparing primary school teachers in a higher educational institution as highly educated specialists capable of flexibly reformatting the direction and content of their own professional activities, selecting new forms, methods, and teaching aids has an impact on becoming and the formation of dominant motives of young learners during labor training.

\section{LITERATURE REVIEW}

The dominant imperatives of the new strategy of vocational training of specialists from the standpoint of the new philosophy of education have been recently clarified by S. Goncharenko (2013), I. Zaziun (2004), V. Kremen (2011) et al. Peculiarities of general pedagogical teacher preparation are studied by D. Barton, S. Batrtlett (2007), A. Bogush (2012), O. Dubaseniuk (2017), M. Yevtukh (2002), L. Koval (2012), T. Koycheva (2017), A. Kuzminskyi (2011), L. Savchenko (2018), V. Semychenko (2010) et al. In the field of primary school pedagogy, the works of V. Balakirieva (2015), N. Bibik (2020), O. Bida (2019), V. Bondar (2003), A. A. Delhaxe (2009), S. MacDonald (2004), I. Palshkova (2019), O. Savchenko (2015), L. Sandbarg (2001), M. Skatkin (1990), L. Khomich (1998), I. Shaposhnikova (2013) are of fundamental importance.

Despite the undeniable achievements in the development of productive labor, the national science lacks holistic studies focused on the problem of preparing primary school teachers for labor training of young learners. The analysis of pedagogical references revealed a rather small number of studies in terms of reassessment and understanding of the historical experience related to the organization of young learners' labor training. At the same time, the practice of solving the issues on the organization and involvement of young learners in labor training in primary schools is of significant scientific value for developing theoretical and organizational-methodological principles of young learners' labor training in modern conditions. 
The purpose of the article is to analyze the preparation of future primary school teachers for the organization of young learners' labor training during the educational process in a higher educational institution.

Objectives of the article: 1 . To reveal the essence and structure of the "readiness of future teachers to organize labor training of young learners" phenomenon; 2. To monitor the preparation of future primary school teachers for the organization of young learners' labor training during the educational process in a higher educational institution; 3. To discuss the problems of the school subject "Labor training" and to develop forms and methods for preparing future primary school teachers to organize labor training.

\section{METHODS}

In order to reach the study objectives, the authors used the following theoretical methods: analysis (retrospective and comparative) of psychological and pedagogical references, generalization and classification of scientific data in philosophical, psychological and pedagogical, educational and methodical sources for defining the state and theoretical substantiation of key concepts and categories of the study on preparing future primary school teachers for the "Labor training" and "Labor" subjects. In order to study the quality of educational services of future professionals, the authors used the following empirical methods: diagnostic (questionnaires, surveys, and testing) methods for determining the results of academic performance, as well as monitoring of the preparation of future primary school teachers (Dubovitskaya, 2005; Delhaxhe, 2009). In order to carry out the diagnosis in educational institutions, a survey was conducted among 49 teachers. The survey was aimed at checking the quality of students' knowledge. The developed questionnaire is original. The nature of learning motivation was determined using the method of M. Matyukhina (1984). Trying to get objective results, the authors largely used the following methods: observations, discussions, and mini answers to questions, essays for a given topic, as well as questionnaires for students, parents, and teachers. The authors developed Questionnaire 1. Ideas about the essence of labor training and Questionnaire 2. The level of attitude to educational activities and self-control, as well as task-situations on organizing labor training (the questionnaires are original).

\section{RESULTS}

Vocational training is defined as a process of forming a specialist for one of the areas of labor activity related to mastering a certain type of occupation, profession (Delhaxhe, 2009, p. 222-223). Vocational training is not the same as vocational education. It is not synonymous with professional development and professional adaptation, either, although these processes are interrelated in the development of a specialist. It is a set of special knowledge, skills and abilities, qualities, practical experience and standards of behavior that provide the opportunity to work successfully in a particular profession. It is also a process of communicating relevant knowledge (Orlov, 2003, p. 1213). Accordingly, in special psychological and pedagogical references, as well as in their dissertations, the authors often do not consider this category in detail, and use it for studying with other concepts. The latter is probably due to the fact that the concept of "readiness" is widely used, and its meaning seems to be quite clear. However, it is assumed that a special reference to the essence of this concept may more accurately define its content, interpretation in modern references, and this will help to determine its place in the study and ways to relate to other concepts.

Vocational training will be interpreted as a process of acquiring knowledge, skills, and abilities that enable performing work in a particular field of activity. 
Psychologists consider preparedness as a special mental state that arises as a manifestation of a qualitative neoplasm in the structure of personality at a certain stage of its development. The analysis of the published studies proves that nowadays, there is a powerful information base on the essence and the content of preparing future teachers. At the same time, a number of issues related to preparing future teachers for the organization of labor training do not have a convincing and reasoned solution, although the need for this is increasingly realized in theory and in practice.

Thus, the readiness of future primary school teachers to organize labor training is interpreted as a result of preparing students when studying in a higher pedagogical institution, as the state of the future teacher who has mastered the system of knowledge of productive, project technologies. The formation of future primary school teachers' readiness is not a spontaneous or involuntary process. This is a systematic and purposeful activity whose success is impossible without revealing "structural links" of the personality that are indicators of the students' readiness for the productive labor activity with young learners.

The authors consider the preparation of future primary school teachers for professional pedagogical activity as a holistic educational and pedagogical process aimed at forming in students a system of necessary knowledge, skills, and abilities for productive work of young learners, providing them with methods and techniques to turn productive technologies to the project activities, as well as the formation of a professionally-focused creative personality of the future teacher.

The research and experimental work were carried out at the Kryvyi Rih State Pedagogical University, the South Ukrainian Pedagogical University named after K. D. Ushynsky, and the Kirovograd State Pedagogical University named after V. Vynnychenko. Various types of studies covered 360 students, 49 higher school teachers, and 89 school teachers.

According to the survey of teachers, only (14.2\%) formulates the concept of labor training completely, clearly, and reasonably; $57.1 \%$ of the respondents identify labor training with work, and the rest of the teachers (28.7\%) formulate the concept by giving specific examples.

According to $85.8 \%$ of the respondents, the organization of labor training is an urgent need of a modern school, while $14.2 \%$ indicate that the organization of such training requires much time and effort, which does not always justify itself.

The teachers indicated the following difficulties: the lack of learners' positive learning motivation $-85.7 \%$, which does not ensure the efficiency of performing tasks, the need in defining learners' individual characteristics and their typological grouping $-42.8 \%$, the organization of group work $-71.4 \%$, the organization of independent work $-42.8 \%$, and the lack of time for preparing materials $-100 \%$.

The answers for the question What forms of learning organization, apart from the lesson, do you use? were as follows: $76.0 \%$ of the surveyed teachers use classes in the extended daycare groups, $18.0 \%$ use afterschool programs, $43.3 \%$ - game lessons (project defense, travel lessons), and $12.0 \%$ - educational excursions. It is possible to see that most teachers realize the need to introduce a set of various forms of learning adapted to school conditions and age characteristics of students into the educational process (various types of lessons, consultations, conferences, interviews, etc.) to overcome the leveling in the learning process.

According to the survey, the following verbal methods are most often used by teachers: discussions (44.0\%), games (60.0\%), storytelling (14.0\%), and disputes (1.7\%). The teachers mentioned the following visual methods: paintings, illustrations, drawings (93.3\%), tables (14.0\%), demonstrations $(21.3 \%)$, presentations $(21.3 \%)$, and schemes $(1.0 \%)$. The practical methods included manual labor (36.7\%).

The trend of residual funding of education by the state caused the disability of many schools to update classrooms and buy new equipment. There is a lack of visual means. All this has a negative impact on the quality of education and reduces young learners' interest in lessons. This study 
confirmed this trend and showed that only $29.0 \%$ of the surveyed teachers rated the equipment of the educational process in their subject as good, $61.0 \%$ rated the equipment availability as satisfactory, and $10.0 \%$ rated it as "unsatisfactory rather than satisfactory."

The nature of learning motivation was determined by using the method of M. Matyukhina (1984, p. 149-150) that allowed identifying the leading, dominant motives in the learners' motivation. All motives indicated in this method can be classified into broad social (motives of duty and responsibility, self-determination and self-improvement), narrow personal (well-being and prestige), educational and cognitive (related to the content and process of learning), and those for the trouble prevention.

According to testing learners from 4-A (25 learners) and 4-B (25 learners), social motives dominated in the learners' learning motivation. This is $52 \%$ of the learners from $4-A$ and $48 \%$ of those from 4-B. Twelve percent and $8 \%$ of the learners from the fourth form have narrow personal motives in learning, respectively. The rest of the learners displayed the availability of educational and cognitive motives. This is $36 \%$ of the learners from $4-A$ and $44 \%$ of those from $4-B$. In addition, as for the learners' educational and cognitive motives, those of the educational content predominate ( $28 \%$ of the learners from $4-A$ and $4-B$ ). Thus, the learners under the study find it extremely important to be recognized by the teacher and parents, as well as to have trusting relationships with age mates and obtain the opportunity to get a high mark in the class.

Subject to the proper preparation for school, children are usually optimistic about their school life. Emotionally, they are very vulnerable and easily share opinions about their emotional state with the people they love. Therefore, taking this into account, in order to study the young learners' psychological state, their satisfaction or dissatisfaction with their school life, parents of learners from forms $1-4$ were offered to complete the relevant questionnaire.

The parents' answers were analyzed and classified into three groups: positive attitude, neutral attitude, and indifferent attitude. The results are visually presented in the table and in Fig. 1.

Table 1. Determining the types of young learners' attitudes to learning

\begin{tabular}{|l|l|l|l|}
\hline Attitudes & Form 2 & Form 3 & Form 4 \\
\hline Positive & $46 \%$ & $33 \%$ & $28 \%$ \\
\hline Neutral & $39 \%$ & $50 \%$ & $52 \%$ \\
\hline Indifferent & $15 \%$ & $17 \%$ & $20 \%$ \\
\hline
\end{tabular}


Figure 1. Young learners' attitude to learning

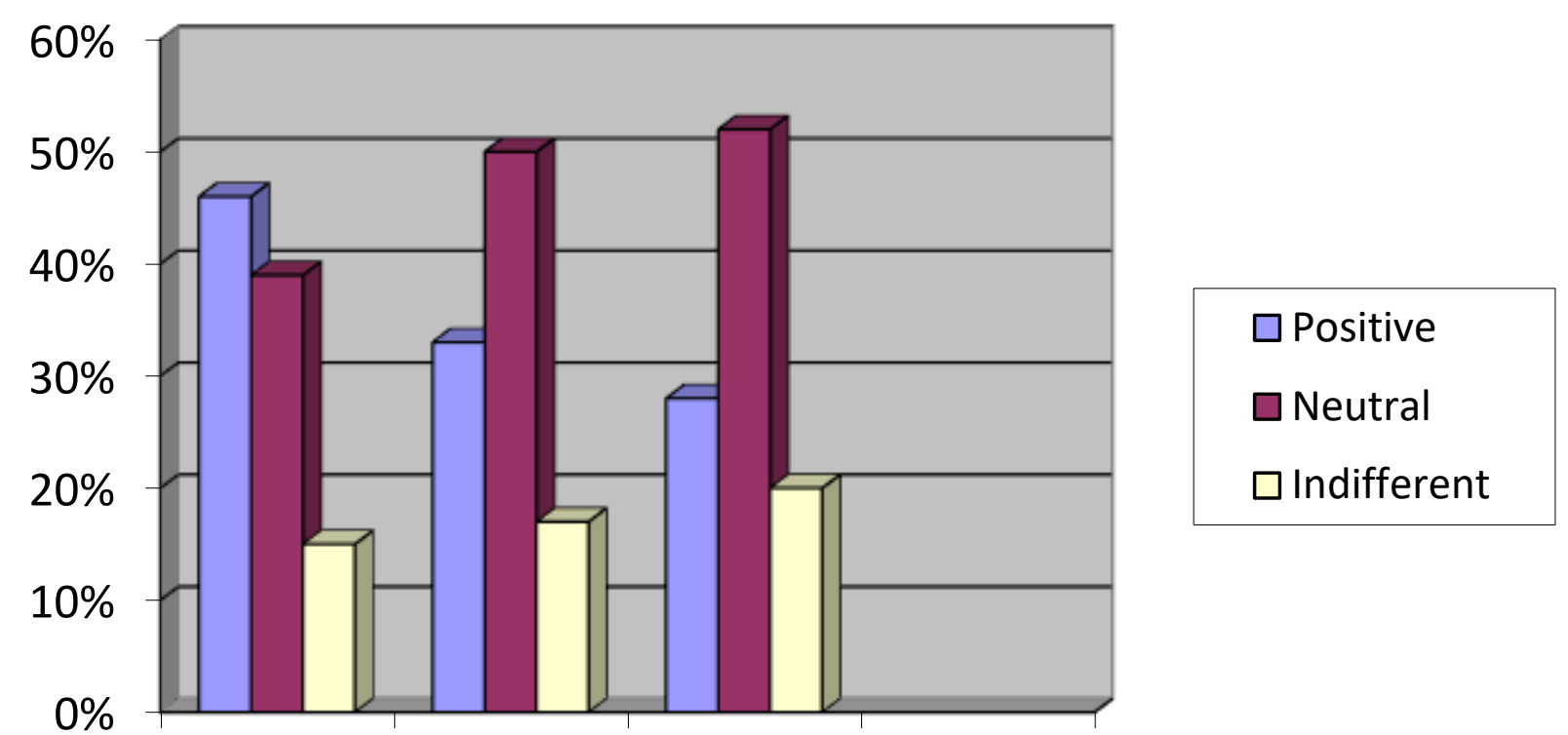

Form 2 Form $3 \quad$ Form 4

The analysis of the table confirmed that a responsible attitude to learning largely depended on the motives guiding a learner during labor training. Thus, $46 \%$ of the learners from the second form, and only $28 \%$ of the learners from the fourth form have the positive attitude. Twenty percent of the learners from the fourth form have the indifferent attitude. Thirty-nine percent of the learners form the second form and $50 \%$ of the learners from the third form have the neutral attitude.

Parents were asked to give mini answers to questions asked by primary school teachers. Below are the examples of questions and answers. The parents often answered: a good and kind person to the question "Who do I see my child in the future?" Answering the second question "What does my child like to do most of all?" the parents wrote that their child liked drawing, helping around the house, dancing, and communicating with friends. Answers to the third question "What does your child value in people most of all?" were almost the same and specified common human qualities: kindness, honesty, decency, obligation, understanding, and gratitude. The most common answers to the fourth question "What does my child dream of?" were a new toy, a bicycle, and a soccer ball. Most of the respondents answered positively to the fifth question "Do I help enough in my child's studies?"

The analysis of the obtained answers gives valuable information about the motivation of learning dynamics and tendencies about the development of a certain learner's attitude to learning, labor activity, and school.

At the ascertaining stage of the experiment, an exhibition of learners' drawings was organized, and the drawings were evaluated according to certain criteria: aesthetics and originality. The children learned to analyze their work and form the ability to think critically and constructively. The authors studied the works of each child and created presentations of drawings. At the formative stage, the exhibitions of works were individual and were evaluated by using game forms and techniques (children's jury, "invent a fairy tale", and "an amulet for our city").

The results of studying these stages of the experimental work are shown in the table and in Fig. 2. 
Table 2. Analysis of the children's works (drawings) by the following criteria: aesthetics, originality

\begin{tabular}{|c|c|c|c|c|c|c|c|c|c|}
\hline \multirow{4}{*}{ No. } & & \multicolumn{8}{|c|}{ Quantitative indicators } \\
\hline & & \multicolumn{4}{|c|}{ Ascertaining experiment } & \multicolumn{4}{|c|}{ Forming experiment } \\
\hline & \multirow[b]{2}{*}{ Levels } & \multicolumn{2}{|c|}{ Control group } & \multicolumn{2}{|c|}{ Experimental group } & \multicolumn{2}{|l|}{ Control group } & \multicolumn{2}{|c|}{ Experimental group } \\
\hline & & $\begin{array}{l}\text { Number } \\
\text { of } \\
\text { children }\end{array}$ & $\%$ & $\begin{array}{l}\text { Number } \\
\text { of } \\
\text { children }\end{array}$ & $\%$ & $\begin{array}{l}\text { Number of } \\
\text { children }\end{array}$ & $\%$ & $\begin{array}{l}\text { Number } \\
\text { of } \\
\text { children }\end{array}$ & $\%$ \\
\hline 1 & High & 2 & 16.67 & 2 & 16.67 & 3 & 25.00 & 5 & 41.67 \\
\hline 2 & Sufficient & 3 & 25.00 & 4 & 33.33 & 4 & 33.33 & 5 & 41.67 \\
\hline 3 & Low & 7 & 58.33 & 6 & 50.00 & 5 & 41.67 & 2 & 16.67 \\
\hline
\end{tabular}

Figure 2. Results of analyzing the children's works

Analysis of the children's works (drawings) by the following criteria: aesthetics, originality

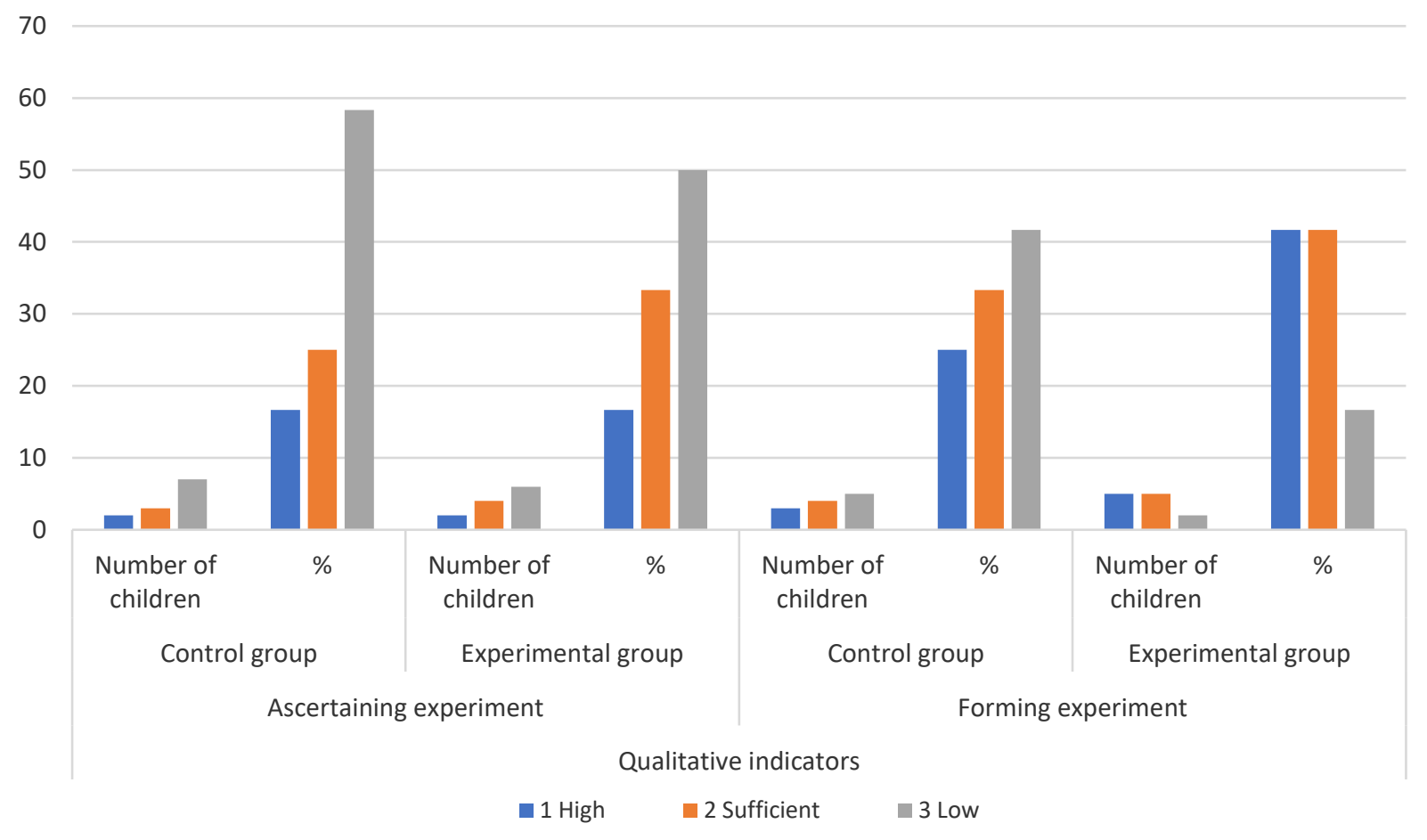

According to the table, only $16.67 \%$ of the children have a high level, and $50 \%$ of them have a low level, which clearly shows that the children's drawings need to be improved and the teaching methods of primary school teachers need to be developed.

In order to identify the gaps of students when they organize learners' labor training, a comprehensive survey was carried out. The following questionnaires were developed: Questionnaire 1. Ideas about the essence of labor training; Questionnaire 2. The level of attitude to educational activities and self-control, as well as task-situations on organizing labor training.

The survey revealed difficulties in understanding the essence of educational activities in their organizational and cognitive aspects by most students. In particular, only $18 \%$ of the surveyed students from the experimental group and $21.8 \%$ of the students from the control group consider it necessary to have a formed and aware concept about the educational activities as an important condition for successful learning of future primary school teachers. It is assumed that $59 \%$ and $60 \%$ 
of the first-year students have it, respectively. However, a clear, consistent, correct, and detailed answer to this question was given by only $23 \%$ of the first-year students from the experimental group and by $31.2 \%$ of the students from the control group; $18 \%$ and $18.2 \%$ of the students made inaccuracies, respectively; the rest of the answers can be attributed to tautologies ("Yes", 42\% of the students from the experimental group and $41.2 \%$ of the students from the control group admit that self-control causes excessive nervousness and insecure actions; $11 \%$ of the students from both groups believe that self-control does not play any role in learning, and only $40 \%$ of the first-year students from the experimental group and $42.7 \%$ of the students from the control group say that self-control helps to optimize their activities).

All the students surveyed need systematic work on developing skills on the organization of labor training. No student considers such work superfluous, which indicates serious adaptive problems the first-year students have ("this is the main activity of students", "this is to work at in the classroom", etc.).

Summing up the results of the survey, it is possible to say that, firstly, the authors did not reveal any special differences in the content and problems of the educational activities of the students from two experimental groups. Secondly, only $30 \%$ of the students, i.e., each third, feel like a subject of the educational activity and try to form full-fledged partnerships with other participants in the educational process - students, teachers, tutors, etc. Thirdly, only $40 \%$ of the students feel the need to form their own learning activities and such an important element as selfcontrol. Fourthly, according to $42 \%$ of the students, in their activities, the teacher's control dominates over the self-control, and this circumstance prevents them from taking responsibility for learning results and self-management in educational activities. Fifthly, $62 \%$ of the respondents find it rather difficult to set goals, plan, analyze, adjust and carry out self-control in educational activities.

\section{DISCUSSION}

Labor training in primary school is an important link in the system of subjects aimed at the comprehensive harmonious development of learners. It aims at developing the personality by involving learners in creative work, forming a constructive approach to solving work problems.

Labor training is an important means of comprehensive development of primary school learners if it is planned correctly, taking into account the learners' age and physiological characteristics. The experimental studies carried out by doctors have shown that the alternation of practical work in creative workshops with classroom activities increases the efficiency of primary school learners and has a positive effect on the development of practical knowledge and skills. During labor training classes, learners' physical activity is combined with mental activity, because learners have to solve a number of creative tasks (product design, development of step-by-step technology of their production, etc.). At the same time, young learners use their knowledge of the basics of science and materials technology, as well as acquire new knowledge. Thus, labor training comes with the intense mental activity, which helps to raise the learners' intellectual abilities.

Textbooks on labor training present such components as "Designing movable models from cardboard and paper", "Story cutout", "Origami", "Production of three-dimensional artificial flowers", "Collage", "Work with plasticine", "Beadwork", "Work with modern artificial materials", "Weaving", "Embroidery", "Volume application of fabric and buttons", "Volume figures of wire", "Decorative panel", "Art decoration and design", and "Self-service. Clothing and footwear", "Papiermâché", "Excursions", "Safety rules", and "Creative workshop", whose content confirms the compliance with the model of the learning process at a certain stage of primary school development in the labor training lesson.

The program of labor training in primary school focuses on the formation of children's constructive approach to solving labor problems and provides for the learners' consistent involvement in the technical creativity when making a variety of products from natural materials, 
paper, fabric, wood, metal, plastics, and waste materials. In particular, the program includes the "Man and technology" module where children learn about the world of technical professions, master the techniques of modeling and design by using parts from the "Designer" and "Architect" sets and various materials on the sample, technical drawing, and own design.

The current state of education necessitates the training of primary school teachers in higher educational establishments as highly educated specialists capable of flexible reformatting of the direction and content of their own professional activities, the selection of new forms, methods and teaching aids.

Nowadays, in the primary education there are many innovations that are one way or another related to the young learners' intellectual development and, accordingly, require high professional culture from a teacher. Thus, the analysis of existing programs and guidelines for primary school, the analysis of the content of scientific conferences and the bank of pedagogical ideas enabled the authors to focus on pedagogical technologies that were experimentally tested in many regions of Ukraine and gave positive results in the learners' intellectual development.

The means of training future teachers for the organization of learners' labor training in the educational process of primary school is a set of educational and methodological support, including work programs of general and special disciplines ("General pedagogy", "Methods of labor training", "Organization of project activities"), methodical manuals, methodical instructions, workbooks, etc.

These are examples of themes for individual tasks: "Teacher of the Ukrainian national school", "Methods of preparing students for lectures, seminars and practical classes", "Formation of students' research skills", "Requirements for pedagogical communication", "Methods of searching for learners' labor training in the primary school educational process", "The modern primary school teacher's image", "Working capacity and conditions to maintain it", "Nonverbal means of the teacher's impact on a primary school learner", "Student's rights and responsibilities", "Future teacher as a researcher of pedagogical phenomena and processes", "Requirements for the personality of a primary school teacher", "The ideal teacher: who is he/she?". The production of a wall newspaper on pedagogical topics can be a possible project.

During their pedagogical practice, second-year students were offered a task, e.g., to write an article: "Family portrait". The families who can share their experience on preparing a child for school are invited to school. Such work with parents is preceded by the preparatory work. The efficient work on preparing a child for school is facilitated by the differentiation of pedagogical comprehensive education of parents that involves taking into account its main aspects (social, demographic, ethnographic, and ideological). In the games, children selected pictures according to the task. These were mostly travel games: "Journey to the books exhibition "Fairytale Heroes", "Long Journeys", "Journey around the city". The pictures were placed in a hall or in another room, where the "travelers" had to go, which gave them certain independence, increased their interest in the game, and enriched the game actions. Pronouncing the counting rhyme, the children were divided into several groups (four, five), according to the tasks of the game. Each group that included two children was given a task: one child had to look at the vegetables grown in the field and select the relevant pictures, the second child had to choose the fruits growing in the garden, and the third one was to name pets, etc. Other children were waiting for "the travelers" who, when returning, placed the pictures on the stands and talked about them, naming the group the animal belonged, i.e., they operated with generalized concepts.

The next group included such games as "Tell me everything you know about the object". The children were given "pictures-letters" to be "read". These were such games as "School", "Sports", "Shop", "Vegetable and fruit market", "Guess", "Puzzles", "Story games", "Car", etc.

Repeating the game, the students gave the children two "picture sheets" depicting objects and offered to tell what they looked like and what differences they had, as well as name the group they belonged to. The games of this type helped to consolidate the children's ability to analyze, 
synthesize, combine objects into one group based on comparison and finding common or similar features.

The students were offered probable project themes: "Methods of research on productive work", "Subject and essence of scientific activity", "Sources of scientific information on labor training and their use in scientific work", "Students' research work", "Basic forms of implementing research results", "Research of the students' organization of labor activity during various forms of education".

Thus, the suggested variety of forms and methods of work had a positive impact on the formation of a positive attitude to learning and indicators of preparing learners for labor training.

\section{CONCLUSION}

Based on the analysis of scientific references, the readiness of future primary school teachers to organize labor training is interpreted as a result of preparing students during their studies at a higher pedagogical institution, as the state of the future teacher who has mastered the system of knowledge of productive, project technologies. The formation of future primary school teachers' readiness is not a spontaneous or involuntary process. This is a systematic and purposeful activity whose success is impossible without revealing "structural links" of the personality that are indicators of the students' readiness for the productive labor activity with young learners.

The survey of young learners made it possible to determine what children were most interested in and what kind of work they liked. The analysis of the obtained data shows that if there is free time, only $8 \%$ of the learners like making souvenirs from various materials (cardboard, natural materials, textiles), being active in labor lessons. The other $29 \%$ of the young learners are rarely active. They spend an hour every other day for their favorite activity. This has given valuable material about the motivation of the learning dynamics and tendencies about the development of a certain learner's attitude to the labor activity. Analyzing the students' productive labor activity, the authors noticed that only $12 \%$ of the students from the control group and $11 \%$ of the students from the experimental group worked at the handiworks themselves and creatively. The other students worked using samples and illustrations. According to the analysis of various students' works, it has been revealed that a small number of future primary school teachers are able to make and artistically decorate handiworks from various materials.

Thus, the hypothesis of the study has been proved: the dominant motives of young learners determine a responsible attitude to learning and largely depend on the motives guiding a learner during labor training. The need in preparing primary school teachers in a higher educational institution as highly educated specialists capable of flexibly reformatting the direction and content of their own professional activities, selecting new forms, methods, and teaching aids has an impact on becoming and the formation of dominant motives of young learners during labor training.

The learners' work during the formation of the national education system was characterized by the adaptation to the new market conditions of management where its organization was subject to the requirements of self-financing. An important condition for the efficient productive work in secondary schools is the fruitful work and pedagogical skills of their leaders and teachers of labor training who use the experience of teaching methods to ensure the organization of learners' work in the educational process at a high professional and pedagogical level. The further work can be continued by developing pedagogical conditions for improving productive work of future primary school teachers.

Authors' Contributions: Iryna Oleksandrivna Palshkova: designed the study, prepared the plan, wrote the first draft of the manuscript and edited the final version. Viktoriia Anatoliivna Balakirieva: designed the study, prepared the plan, wrote the first draft of the manuscript and edited the final version. Marianna Volodymyrivna Skoromna: designed the study, prepared the plan, wrote the first draft of the manuscript and edited the final version. Yuliia Anatoliivna 
Shpaliarenko: designed the study, prepared the plan, wrote the first draft of the manuscript and edited the final version. All authors have read and approved the final version of the manuscript.

Ethics Approval: Not applicable.

Acknowledgments: Not applicable.

\section{REFERENCES}

Balakirieva, V. (2015). Historical and pedagogical review of the development of the problem of students' labor training, Science and Education, 8, 7-11.

Bibik, N. (2020). Kompetentnist i kompetentsiyi u rezultatakh pochatkovoyi osvity [Competence and competencies in the results of primary education]. Primary School, 9, 1-15.

Bogush, A.M. (2012). Vektor nastupnosti derzhavnykh standartiv doshkilnoyi i pochatkovoyi lanok osvity [Vector continuity of state standards of preschool and primary education]. Scientific Bulletin of the Sukhomlynsky MSU. Mykolaiv, 1(37), 46-49.

Bondar, V., Shaposhnikova, I. (2003). Adaptyvne navchannya studentiv yak peredumova realizatsiyi kompetentnisnoho pidkhodu do profesiynoyi pidhotovky vchytelya [Adaptive learning of students as a prerequisite for the implementation of a competency-based approach to teacher training]. Native School, 11, 36-41.

Bartlett, S., Burton, D. (2007). Introduction to education studies. London: SAGE.

Delhaxhe, A. (2009). Arts and Cultural Education at School in Europe. Brussels: Eurydice.

Dubaseniuk, O. (2017). Metodyka vykladannya pedahohiky [Methodology of Teaching Pedagogy]. Zhytomyr.

Dubovitskaya, T.D. (2005). K probleme dyahnostyky uchebnoy motyvatsyy [On Diagnosis of Educational Motivation]. Issues of Psychology, 1, $73-78$.

Goncharenko, S. (2013). Naukovi shkoly u pedahohitsi [Scientific Schools in Pedagogy]. Education of Adults: Theory, Experience, and Perspectives, 6, 7-28.

Khomich, L.O. (1998). Profesiyno-pedahohichna pidhotovka vchytelya pochatkovykh klasiv [Professional and pedagogical training of a primary school teacher]. Kyiv: Magister-S.

Kniazheva, I. A., Koychev, T.I. (2017). Tekhnolohiya vykorystannya dydaktychnykh bahatovymirnykh instrumentiv u profesiyniy pidhotovtsi maybutnikh vykladachiv [Technology of using didactic multidimensional instruments in professional training of future teachers]. Web of Science. Science and Education: scientific and practical bulletin, 12, $190-195$.

Koval, L.V. (2012). Suchasna pochatkova osvita: vektory rozvytku [spetsialnyy vypusk, prysvyachenyy 80-richchyu universytetu [Modern primary education: development vectors [special issue devoted to the 80th anniversary of the University]. Berdiansk: BSPU.

Kovshar, E., Palshkova, I., Savchenko, L. (2019). Interaction of Productive and Interactive Technologies in the Educational Process of Higher School. Amazonia Investiga, 8(20), 229-235.

Kremen, V. (2011). Struktura modernizatsiyi osvity v konteksti tsyvilizatsiynykh zmin [Structure of modernizing education in the context of civilizational changes]. Pedagogy and Psychology, 2, 5-13.

Kuzminskyi, A., Bida, O., Kuchap, O., Yezhova, O., Kuchai, T. (2019). Information Support of Educationalists as an Important Function of a Postgraduate Education System. Romanian Journal for Multidimensional Education, 11(3), 263-279

Kuzminskyi, A.I. (2011). Pedahohika vyshchoyi shkoly [Tertiary Education: manual for students of higher educational establishments]. Kyiv: Znannia.

Macdonald, S. (2004). The History and Philosophy of Art Education. Cambridge: The Lutterworth Press.

Matyuhina, M.V. (1984). Vozrastnaya y pedahohycheskaya psykholohyya [Developmental and pedagogical psychology]: Manual for students of pedagogical institutes, specialty No. 2121 "Pedagogy and Methodology of Primary School". Moscow: Prosveshchenie.

Orlov, V.F. (2003). Profesiyne stanovlennya maybutnikh vchyteliv mystetskykh dystsyplin: teoriya i praktyka [Professional becoming of future teachers of art disciplines: theory and practice]: monograph. Kyiv: Naukova Dumka. 
Savchenko, L. (2018). Functional role of monitoring in assessing the quality of future handicraft teacher training. Science and education, 2, 186-192. https://doi.org/10.24195/2414-4665-2018-2-25

Savchenko, O. (2015). Kompetentnisna spryamovanist novykh navchalnykh prohram dlya pochatkovoyi shkoly [Competence focus of new educational programs for primary school]. Mountain School of the Ukrainian Carpathians, $12-13,38-43$.

Semichenko, V. (2010). Problema osobystisnoho rozvytku y samorozvytku v konteksti neperervnoyi profesiynoyi osvity [Problem of the personal development and self-development in the context of professional education]. Pedagogy and Psychology, 2, 46-57.

Skatkin, M.N. (1990). Pedahohyka [Pedagogy]. Moscow: Pedagogy.

Sundburg, L. A. (2001). Holistic approach to competence development. Systems Res. and Behav. Sci., 18, $103-114$.

Yevtukh, M. B. (2002). Sotsialna pedahohika [Social Pedagogy]. Kyiv: MAUP.

Ziaziun, I. A. (2004). Pedahohichna maysternist [Art of teaching]: Textbook. High School.

Received: 10 June 2021 | Accepted: 2 July 2021 | Published: 22 July 2021

This is an Open Access article distributed under the terms of the Creative Commons Attribution License, which permits unrestricted use, distribution, and reproduction in any medium, provided the original work is properly cited. 